infiltrates and respiratory failure in the acquired immunodeficiency syndrome. Ann Intern Med 1985;102:471-5.

12 Hamm PG, Judson MA, Aranda CP. Diagnosis of pulmonary Kaposi's sarcoma with fibreoptic bronchoscopy and endobronchial biopsy. Cancer 1987;59:807-10.

13 Nash G, Fligiel S. Kaposi's sarcoma presenting as pulmonary disease in the acquired immunodeficiency syndrome: diagnosis by lung biopsy. Hum Pathol 1984;15:999-1001.

14 Gagliard AJ, White DA, Stover DE, Zaman MB. A noninvasive index for the diagnosis of (PCP) in patients with
(AIDS) [abstract]. Am Rev Respir Dis 1986;132:(suppl): A183.

15 O'Donnell CR, Bader MB, Zibrak JD, Jensen WA, Rose RM. Abnormal airway function in individuals with the acquired immunodeficiency syndrome. Chest 1988;94: $945-8$

16 Stover DE, White DA, Romano PA, Gellene RA, Robeson WA. Spectrum of pulmonary diseases associated with the acquired immunodeficiency syndrome. Am J Med 1985; 78:429-37.

\section{A rewarding combination}

I am sure that variety provides stimulus and satisfaction in the practice of medicine. One of the most stimulating periods in my life was working with Dr John Gilson, under Professor Charles Fletcher, at the Medical Research Council Pneumoconiosis Research Unit. Tests of lung function were then non-existent, apart from measurement of vital capacity; so we had all the interest of developing them. But after seven years at that unit the frequent rain of South Wales depressed me, so I applied to go as senior lecturer in the new department of medicine in Jamaica, then British West Indies. "Do you think you are wise to leave the MRC?" was the only comment from Professor Witts, whom I knew from my days as his registrar at Oxford. Yes, indeed I was wise as that too provided exciting but different work. At first I rushed about as if I were in Britain and tried to pursue work in respiratory research. But that was really inappropriate to medicine in Jamaica, so I changed my research interest to diabetes because of its unusual clinical presentation there. Jamaican life held all sorts of fascination and I particularly enjoyed an expedition we organised from the university in Jamaica to climb mountains rising to $6000 \mathrm{~m}$ on the Colombian-Venezuelan border. My brief contact with the local Indians then made me long to learn more of their lives. But after a bit I began to feel unsettled, rather as if I were on a long holiday, even though I was working very hard at the new university hospital.

By then the Medical Research Council had employed Dr Kemp Fowler, an Australian physicist, to design a mass spectrometer specifically for clinical respiratory work; so I had the chance of returning to Britain as director of an MRC respiratory research unit at the Royal Postgraduate Medical School in Hammersmith Hospital. What a change that was from Jamaica! It was immensely stimulating, with the brilliant weekly staff rounds created by Professor Sir John McMichael. Then, one dull grey day in Hammersmith, John McMichael said at lunch that he had been asked to give some lectures in Bogotá, Colombia, and did not wish to go himself. He asked if anyone might be interested. I readily volunteered, gave the lectures on respiratory medicine at the Juan de Dioz Hospital, and after I had finished the lectures headed for the South American forests to canoe down the rivers with the local Indians, whom I had wanted to study since the previous climbing expedition. I was able to share their lives, learn to use a blowgun in the forest, and contribute some medical help as well as amateur dentistry.

From that time onwards I have somehow managed to combine sophisticated medicine in Britain with work in third world countries. This has meant working hard in London for a long stretch and then, about every other year, taking off a month or so to go on an expedition to some remote part of the world. It is a rewarding combination and I would fully recommend a spell of practising medicine in the developing world to any registrar despairing of an immediate consultant job here in Britain.

PHILIP HUGH-JONES 